Fall 2017

\title{
Philosophy Bakes No Bread
}

Babette Babich

Fordham University, babich@fordham.edu

Follow this and additional works at: https://fordham.bepress.com/phil_babich

Part of the Ecology and Evolutionary Biology Commons, Environmental Health Commons, Environmental Public Health Commons, Environmental Studies Commons, Ethics and Political Philosophy Commons, History of Philosophy Commons, Other Philosophy Commons, Other Social and Behavioral Sciences Commons, Outdoor Education Commons, Public Policy Commons, and the Social Policy Commons

\section{Recommended Citation}

Babich, Babette, "Philosophy Bakes No Bread" (2017). Articles and Chapters in Academic Book Collections. 84.

https://fordham.bepress.com/phil_babich/84

This Book Chapter is brought to you for free and open access by the Philosophy at DigitalResearch@Fordham. It has been accepted for inclusion in Articles and Chapters in Academic Book Collections by an authorized administrator of DigitalResearch@Fordham. For more information, please contact considine@fordham.edu. 
Philosophy Bakes No Bread
Philosophy of the Social Sciences

(C) The Author(s) 2017

Reprints and permissions: sagepub.com/journalsPermissions.nav DOI: I0.I I77/0048393 I I 7740827 journals.sagepub.com/home/pos

@SAGE

\title{
Babette Babich ${ }^{1,2}$
}

\begin{abstract}
Far from baking bread, far from practical applicability, philosophy traditionally sought to explain the world, ideally so. Thus, when Marx argued that it was high time philosophy "change the world," his was a revolutionary challenge. Today, philosophy is an analytic affair and analytic philosophers seek less to explain the world than to squirrel out arguments or, more descriptively, to resolve the minutiae of this or that name problem. Faced with diminishing student demand, analytic philosophers have taken to urging that everyone from primary school students to scientists be required to study (analytic) philosophy. Just so, applied philosophers demand to be engaged as consultants on practical projects. Granting that the demand that philosophers be appointed to public policy projects is understandable, inasmuch as everyone, as Hegel observed, desires recognition, this article argues that no argument has been made that the results would benefit any but the appointees while reinforcing current administrative quantitative evaluative schemes.
\end{abstract}

\section{Keywords}

analytic-continental divide in philosophy, applied philosophy, fundraising, marketing, public recognition

Received 2 October 2017

'Fordham University, New York, NY, USA

2University of Winchester, UK

Corresponding Author:

Babette Babich, Department of Philosophy, Fordham University, II 3 West 60th St., 925H,

New York, NY 10023, USA.

Email: babich@fordham.edu 
My teacher, Hans-Georg Gadamer (1900-2002), was fond of relating the cliché: "philosophy bakes no bread." Given Heidegger's reflections on bread (and wine), inspired by the poets Hölderlin, Trakl, and George, the challenge would not be to bake but to think bread, from the sheltering of the seed (Monsanto is part of this) to the labor of the farmers, where Heidegger turns to the poet's reflection on the gift of bread to offer a guest, a wanderer, welcome: the work of hands, the work of the harvest, the gift of nature itself.

In their book, Socrates Tenured-borrowing just a bit from Jon Huer's Tenure for Socrates, published 25 years ago ${ }^{1}$ - Robert Frodeman and Adam Briggle work out their version of this problem, mapping a program for a solution, part of which involves colonizing other disciplines (under the rubric of interdisciplinarity) and part of which involves appointing philosophers to political roles or in some fashion arranging to have philosophers heard by public agencies especially relevant to those legislating or debating or implementing environmental policy.

Frodeman and Briggle are not alone in calling for philosophical relevance, and one can add authors like Alain de Botton and, with more "impact," Nigel Warburton, ${ }^{2}$ but also Rebecca Newberger Goldstein ${ }^{3}$ and the sociologist (and Pittsburgh trained philosopher of science), Steve Fuller, who offers several takes on the issue. ${ }^{4}$

Most of Frodeman and Briggle's debate is informed by a Deweyesque view of philosophy, yet little empirical attention is paid to those philosophers who have actually held elected office (like Gianni Vattimo) or have otherwise been involved with federal government (like Luce Irigaray), nor indeed to names like Jürgen Habermas, impressive in the context of Germany, which

\footnotetext{
${ }^{1}$ Frodeman and Briggle (2016), echo the currently revived clamor for the dissolution of tenure. Cf. Kimball (1990) and Huer (1991). Frodeman/Briggle and Huer plead for increasing interaction between society and academia, arguing that some integration should - and here both books depart from Plato's Socrates - correspond to society's avowed interests and concerns rather than academic philosophy's. See Chomsky and Herman (1988). The failure to mention Chomsky is as problematic as the failure to mention Theodor Adorno, Peter Sloterdijk, or perhaps the most public intellectual of all: Slavoj Žižek.

${ }^{2}$ Nigel Warburton has developed a career and a reputation on a redefinition of philosophical publishing that is fairly close on most levels to what Frodeman and Briggle seem to be calling for in Warburton and Edmonds (2010).

${ }^{3}$ See Goldstein (2014).

${ }^{4}$ Fuller (2009) is concerned with "knowledge management" and therefore "impact" but also and rather wonderfully, with improvisation as well. And see too, Fuller (2005) Useful here is a comparison with Baert (2016), Weinstein (2014), and Posner (2001).
} 
gets as little airtime as Greece or France in the larger framework, mostly Anglophone, indeed mostly American, of the debate.

What is at issue for Frodeman and Briggle, and arguably for others seeking "impact" seems to center on the matter of getting philosophy funded. Thus, their book can read, in part, like a "kickstarter" or "go-fund-me" campaign. Behind this ambition may be the sundry messages of the administration noticing that where the sciences, natural and social, manage to bring in grants to the university, philosophy is rather far behind, occasionally landing some foundation grant, occasionally garnering some National Endowment for the Humanities (NEH) support but not at the National Science Foundation (NSF) level enjoyed by the natural (and to a lesser extent, the social) sciences.

Perhaps Frodeman and Briggle are tired of doing applied philosophy and noticing how little application applied philosophy seems to garner in the socalled "real world." And yet when philosophers manage to bring in funds, that "support" is used by the university at least to some extent just as the university sees fit. Here, philosophy is in the same boat as all the other departments, including the sciences.

Thus, the university may be the problem, and Frodeman and Briggle want more than just a share of the pie. They want to do more than to contribute to the university via indirect costs charged back to their grants. They have their eye on the golden ring of praxis, as Karl Marx concluded his Theses on Feuerbach, turning the applied deficits of the profession on its head where it has remained ever since: contemplating the elusive goal of changing the world.

Frodeman and Briggle argue that this can only mean enjoying appointments in an official regard, assuring a hearing from more important folk in the public sphere (whoever they may be, wherever that may be located, and however that hearing is further to be secured) just so that philosophy (which, as our authors assure their readers, may rightly be assumed to know the answer to the question of what is to be done) can get that right answer to the right ears such that something might be done-rightly.

A good many scholars, cultural critics, sociologists, political philosophers have written on the same matter of "impact," the popular technical term in UK academia, which is all about having one's voice heard in the public sphere, making a difference in society, using standards such as op-ed pieces, legislation, appearances on the news (social media can help: Twitter, Facebook, the awful LinkedIn), all the way up to being known as a national name (maybe Žižek has tips?), as many sports figures are known, and in general having the sense of being as important and as listened to on the street as they might be in their classrooms. But really, more than getting one's name 
known on social media, what it is really about is the getting of funding, ideally via corporate sponsorship for those same notions and projects, where (and we are back to this once more) "indirect costs" benefit the corporate university model.

In addition to the securing of funds, there are elements of philosophy as therapy here (an applied project that flourishes and dies at intervals nor has analytic philosophy helped much), elements of the general conundrum of applied ethics (all such courses and oxymoronic challenges endemic to things such as business ethics or medical ethics or factory farming ethics) thus returning us to Kant's old saw. And if there are already a great number of articles and books written on this theme, we can balloon the numbers if we include the curmudgeons like Roger Scruton (in spite of himself) and Brian Leiter (ergo the anti-Voldemort as Leiter's project does seem to include having people say his name... .). ${ }^{5}$

The impetus to broaden reflection echoes the American Philosophical Association's own call for philosophers to embrace the role of public intellectual ${ }^{6}$ but the problem, and although Frodeman and Briggle make gestures in responding to this (they do not quite get there), remains that of generating public interest.

Attracting interest is the problem of most start-ups, that is, most entrepreneurial ideas. Here, one has a widget, in this case, one has philosophy (and already defining it would be a problem, hence the silencing of any mention of the analytic-continental divide, which analysts contend not to be a divide, the better to ignore it), ${ }^{7}$ but the widget could be some other thing: maybe a new twist on an old thing, like tiny cupcakes, or a device for cleaning something, and the challenge is to get that putative new thing to the market such that one can find buyers, that is, a public, an audience: consumers.

${ }^{5}$ Holland (2013) discusses some of the issues involved with regard not to Leiter but Voldemort.

${ }^{6}$ The APA Committee on Public Philosophy is stated as founded "On the belief that the broader presence of philosophy in public life is important both to our society and to our profession, the basic charge of the committee will be to find and create opportunities to demonstrate the personal value and social usefulness of philosophy." http://www.apaonline.org/members/group.aspx?id=110441. And John Lachs (2009) attributes the becalmed status of philosophical public presence to a "lack of initiative" on the part of professors of philosophy.

${ }^{7}$ See Bateman and Babich (2016). Note that Brian Leiter who chimed in with characteristic violence ('characteristic' of many responses to woman academics on social media), considers himself "continental." 
In a capitalist era, shored up against any market failure, the problem of the market is more complex than mention of the culture industry.

Given that most of us have not read Adorno, film representations may help us. The souk-style markets of scavenged tech debris fetishized as valuable raw materials (the dream of recycling for profit and world salvation) captivated Star Wars fans, the same bad-tech schema dominated Road Warrior and it is still to be seen in the newest Blade Runner 2049, where, such is the market, capitalism provides the only sanctuary at the end, immune to surveillance and drone attacks, incarnate in the separate corporation headed by Deckard's daughter (conceived with the prototype replicant Rachael), Dr. Ana Stelline, her corporate safety secured by copyright (owing to her explicit refusal to be bought out by Neander Wallace's corporation) and living in a bubble (where-else?), techcrafting custom memories ${ }^{\mathrm{TM}}$ essential to Wallace's replicants ${ }^{\mathrm{TM}}$. A tad lower on the scale of cultural sophistication or market capital, we can recall Harry Potter's first trip to Diagon Alley, there to be outfitted with literally magic school supplies, including an owl and a wand - wands the use of which his first teacher, Severus Snape, famously prohibits in class ${ }^{8}$ - highlight the late capitalist ideal of technical complements (geek gear or stuff) and market exchange.

Like capitalism itself, the challenge of getting something on the shelves public is invisible in a consumer society, even given what Adorno names "standardized ubiquity," a term characterizing the paucity of real choice. 9 Oddly even scholars focused on technology and sociology of knowledge, conversant with digital media, seem unaware of the rather more prosaic bubble in which we live - and on the terms of which we publish. Not all good things make it to the market, which is a perfect tautology: what can be found on the supermarket shelves are just the things there are and if old-school socialist markets (à la Eastern Europe in the time of Star Wars, say) dismayed a world of capitalist consumers looking to gloat on all their seeming advantages, showing a lack of choice matched only by a lack of glitter, the putative riches of capitalist markets include more show than substance.

It is not possible to buy anything one might desire in the supermarket market: rather it is only possible to buy what is available there. This is the tautology. The same is true, horror of horrors that it is to dare to say this, of Amazon and other virtual marketplaces. The same is true of video offerings on cable television and YouTube and that is The Hallelujah Effect.

\footnotetext{
${ }^{8}$ See Babich (2015). See on Babich (2017), esp. 100ff.

${ }^{9}$ I talk about "standardized ubiquity" in the music industry updating Horkheimer's and Adorno's reflections on the "Culture Industry" for the YouTube and Facebook era in Babich ([2013] 2016).
} 
Most important perhaps is the conviction for many who have surrendered to the academic rule of analytic philosophy (including Frodeman and Briggle) that all that is needed for "impact" is that philosophers take up the project of being public intellectuals whereupon, so the argument seems to suggest, everything would change. The assumption is that what our world needs is public intellectuals (presumably one can smuggle in the sorts one prefers): like the recent phase of staging "long nights" of analytic philosophy in Paris and New York and Tel Aviv, whereby if one gives them the recognition that is their due, complete with adequate airtime, say: evening talk shows, everything will be great.

But in The Hallelujah Effect, I argue that what is for sale when it comes to media exposure (and this has always been the case with broadcast media, that is, radio and film and television) is not ideas, and not even images or spectacles but just the viewer's attention or consciousness (Babich [2013] 2016).

To date, and to be sure these references are limited to Anglophone spheres, and to the northern hemisphere at that, it is only Slavoj Žižek and Cornel West, followed (just a bit) by Peter Sloterdijk and Judith Butler who have managed to achieve the two things requisite for being public intellectuals: access to prime time television (and social media recognition) along with the not inconsiderable additional detail of having something to say in the process.

These few intellectuals are to be contrasted with the host of wannabes. That is, and you do know them, they are in your department, you may be one yourself, as they populate the university beyond philosophy, this is real interdisciplinarity in practice, beyond Frodeman and Briggle, to be found in other departments: namely, those same political scientists, biologists, environmental scientists, and psychologists routinely hosted for 30 seconds of content so forgettable they have to be asked by university administration to inform their university public relations office about the fact. Philosophers keen to be public intellectuals are often desirous of little more than the chance to join the roster of university "experts" on the mainstream news media rolodex.

Odd here is that academics clamor for the right to be judged by their presence in the marketplace of ideas: which "right" subsequently translates less to giving credit to those who manage to have had some supposed "impact" than, and this should get our attention, to imposing upon all colleagues, especially new recruits, the task of coming up with some way to do so and using the failure or success in the same, this is the Research Excellence Framework (REF), as an evaluative scale. I am only talking about rankings, and that includes measures to hire or to retain or, more grievously, as whole lives are shattered thereby, to dismiss underperforming colleagues. 
This typically extends to a desire to have offending others eliminated from academia or at least one's own department. This is part of the Brexit-effect, and in an age of new jingoism, this can go very far indeed. I have already noted that Brian Leiter is just one example of this, as are those who philosophize in his name, and the spirit of Internet trolling has a good conscience among those philosophers who comment selectively, often anonymously, and with no lack of venom on associated blogs.

Discussion of philosophy in the public sphere benefits from the silencing of the analytic-continental divide and not less from the above equivocation. Hermeneutic reflection comes in handy to parse the equivocation in play for one's colleagues outside philosophy, including those in the public sphere, assume philosophy to be a vastly more traditional thing than it is. Philosophy today is not what your father learned in his college philosophy class nor is it what your university dean might remember having studied. This is, of course, the reason Huer 1991 and Briggle and Frodeman's 2016 books do not reference current philosophical debates but Socrates instead. Their titles are thus a little like radiator grilles on automobiles: chrome and flash, a decorative flourish to give the look of protection from atmospheric dangers.

The very presence of philosophy in the university, as part of the curriculum - sometimes, if increasingly rarely, a required part ${ }^{10}$ - benefits from this sort of equivocation. Philosophy is no longer what it used to be and if the mainstream or analytic dominance of philosophy goes back only a few decades, university philosophy departments predate the divide, such that titles and descriptions in the college catalogue typically have little or no relation to the content of courses as taught.

One's fellow faculty, often those chairing various college-core course committees, assume their colleagues in philosophy to be teaching the kind of philosophy they remember from their own studies. Some even assume scholasticism might be among the dangers of taking courses in philosophy: a sentence to a certain amount of numbered summae, supposed on the whole to be "good" for an undergraduate, or a historically informed reading of Aristotle, including an assumed knowledge of Ancient Greek, than has in fact been on offer for years among the analytic Metaphysics and Epistemology (M\&E) contingent.

Frodeman/Briggle are environmental philosophers, and one issue in environmental philosophy is that philosophy, no matter whether analytic or continentally minded, seems bound to go nowhere, to use the term once again:

${ }^{10} \mathrm{Philosophy}$ is currently an academic requirement at some religious universities but also at the U.S. Military Academy at West Point. 
doomed to lack "impact." If there is global warming, the issue is less to be the question of what to do about it (and how to get that done) than what can seem the challenge of securing a consensus on whether there is or is not such a thing to begin with. While the science is being decided, of course, this is the sort of delay tactic in which corporate law specializes, pollution continues apace, industrial farming proceeds, oil extraction under all its terrible forms proliferates.

When Steve Fuller made the modestly intentioned observation in his 2016 "Science Has Always Been a Bit 'Post-Truth,"” reaction on social media was antagonistic. The reigning assumption in the "fake news," post-truth debate seems to be that science proceeds without passing Go, without attention to funding sources, or to placating peers in an effort to assure good reviews, straight into "Nature" in a search for "the Truth."

As Nietzsche observed more than a century ago, this is a fairy tale.

\section{Declaration of Conflicting Interests}

The author(s) declared no potential conflicts of interest with respect to the research, authorship, and/or publication of this article.

\section{Funding}

The author(s) received no financial support for the research, authorship, and/or publication of this article.

\section{References}

Babich, Babette. (2013) 2016. The Hallelujah Effect: Reflections on Music, Performance Practice, and Technology. London: Routledge.

Babich, Babette. 2015. "Pedagogy and Other Defenses against the Dark Arts: Professor Severus Snape and Harry Potter." The Philosophical Salon: Los Angeles Review of Books, December 28. http://thephilosophicalsalon.com/pedagogy-and-otherdefenses-against-the-dark-arts-professor-severus-snape-and-harry-potter/.

Babich, Babette. 2017. "Tools for Subversion: Illich and Žižek on Changing the World." In Making Communism Hermeneutical: Reading Vattimo and Zabala, edited by Sylvie Mazzinie and Owen Glyn-Williams, 95-111. Frankfurt am Main: Metzler.

Baert, Patrick. 2016. "The Philosopher as Public Intellectual." In Public Intellectuals in the Global Arena: Professors or Pundits, edited by M. Desch, 163-81. Notre Dame: University of Notre Dame Press.

Bateman, Chris, and Babette Babich. 2016. "The Last of the Continental Philosophers: A Dialogue.” http://onlyagame.typepad.com/only_a_game/2016/12/the-last-ofthe-continental-philosophers-a-dialogue.html. 
Chomsky, Noam with Edward S. Herman. 1988. Manufacturing Consent: The Political Economy of the Mass Media. New York: Pantheon Books.

Frodeman, Robert, and Adam Briggle. 2016. Socrates Tenured: The Institutions of 21st Century Philosophy. Lanham: Rowman \& Littlefield.

Fuller, Steve. 2005. The Intellectual. London: Icon.

Fuller, Steve. 2009. The Sociology of Intellectual Life: The Career of the Mind in and around Academy. London: Sage.

Fuller, Steve. 2016. "Science Has Always Been a Bit 'Post-truth." The Guardian, December 15. https://www.theguardian.com/science/political-science/2016/dec/15/ science-has-always-been-a-bit-post-truth

Goldstein, Rebecca. 2014. Plato at the Googleplex: Why Philosophy Won't Go Away. New York: Pantheon Books.

Holland, Nancy. 2013. Ontological Humility: Lord Voldemort and the Philosophers. Albany: State University of New York Press.

Huer, Jon. 1991. Tenure for Socrates: A Study in the Betrayal of the American Professor. Guilford: Greenwood.

Kimball, Roger. 1990. Tenured Radicals: How Politics Has Corrupted Higher Education. New York: HarperCollins.

Lachs, John. 2009. “Can Philosophy Still Produce Public Intellectuals?” Philosophy Now 75:24-27.

Posner, Richard A. 2001. Public Intellectuals: A Study of Decline. Cambridge: Harvard University Press.

Warburton, Nigel with David Edmonds. 2010. Philosophy Bites. Oxford: Oxford University Press.

Weinstein, Jack Russell. 2014. "What Does Public Philosophy Do? (Hint: It Does Not Make Better Citizens).” Essays in Philosophy 15:33-57.

\section{Author Biography}

Babette Babich is Professor of Philosophy at Fordham University, and Executive Editor, New Nietzsche Studies. Selected Articles in PDF: https://fordham.academia. edu/BabetteBabich. Books include her recently edited collection Hermeneutic Philosophies of Social Science (Berlin: de Gruyter, 2017) and recent monographs, Un politique brisé. Le souci d'autrui, l'humanisme, et les juifs chez Heidegger (Paris: L'Harmattan, 2016), and The Hallelujah Effect: Philosophical Reflections on Music, Performance Practice, and Technology (London: Routledge, 2016). Faculty Web Page: http://faculty.fordham.edu/babich/. 